\title{
Oral health and incidence of nosocomial infection and mortality in patients
}

\section{undergoing elective cardiac surgery}

\author{
Saúdle oral e incidência de infecção nosocomial e mortalidadle em pacientes submetidlos a cirurgia \\ cardíaca eletiva
}

Salud bucodental e incidencia de infecciones nosocomiales y mortalidad en pacientes sometidos a cirugía cardíaca electiva

Received: 04/05/2021 | Reviewed: 04/12/2021 | Accept: 04/17/2021 | Published: 05/01/2021

\author{
Gabriela Margraf Gehring \\ ORCID: https://orcid.org/0000-0001-9623-6162 \\ Universidade Estadual de Ponta Grossa, Brazil \\ E-mail: gehring.gabriela@yahoo.com.br \\ Mário Augusto Cray da Costa \\ ORCID: https://orcid.org/0000-0001-9377-9495 \\ Universidade Estadual de Ponta Grossa, Brazil \\ E-mail:drmarioaugusto@uol.com.br \\ Renan Bordini Cardoso \\ ORCID: https://orcid.org/0000-0003-2832-9329 \\ Universidade Estadual de Ponta Grossa, Brazil \\ E-mail: renanctbmf@gmail.com \\ Ana Carolina Mello Fontoura de Souza \\ ORCID: https://orcid.org/0000-0003-2324-1301 \\ Universidade Estadual de Ponta Grossa, Brazil \\ E-mail: acmfs00@gmail.com \\ Marcelo Carlos Bortoluzzi \\ ORCID: https://orcid.org/0000-0003-2756-5047 \\ Universidade Estadual de Ponta Grossa, Brazil \\ E-mail: mbortoluzzi@gmail.com
}

\begin{abstract}
Objective: To analyze the relationship between oral disease and the risk of developing hospital pneumonia, mediastinitis, endocarditis, surgical site infection and hospital death in patients undergoing elective cardiac surgery. Assess which risk factors would be related to the risk of nosocomial infection and death after cardiac surgery. Methodology: It was an analytical, observational, prospective study, carried out from January to December 2018. The study included 46 patients candidates for elective cardiac surgery and evaluated as to the type of heart disease, type of surgery, associated comorbidities, age, NYHA classification, BMI, ICU stay days, oral health assessment by a dental surgeon, occurrence of infection and hospital death. The analysis was done through analysis of absolute and relative frequencies, estimation of odds ratios, chi-square test and Mann-Whitney test. Results: Of the 46 patients analyzed, 11 $(23.9 \%)$ of them had hospital infections and 4 (8.7\%) died, there was no statistically significant difference in the variables studied with the occurrence of infection or death. The heterogeneity of the findings in the oral evaluation that ranged from edentulous patients with partial or total dentures, partial edentulous with or without prosthesis and varying degrees of oral disease that ranged from gingivitis, periodontitis to abscesses. The prostheses had varying degrees of conservation and hygiene. This great variability of findings may have implied no statistical significance in the variables. Conclusion: There was no statistical difference in the occurrence of hospital pneumonia, mediastinitis, endocarditis, surgical site infection and hospital death according to the patients' oral health condition.
\end{abstract}

Keywords: Thoracic surgery; Oral health; Cross infection.

\section{Resumo}

Objetivo: Analisar a relação de doença bucal com o risco de desenvolvimento de pneumonia hospitalar, mediastinite, endocardite, infecção de sítio cirúrgico e óbito hospitalar em pacientes submetidos a cirurgias cardíacas eletivas. Avaliar quais fatores de risco estariam relacionados ao risco de infecção hospitalar e morte pós cirurgias cardíacas. Metodologia: Foi um estudo analítico, observacional, prospectivo, realizado no período de Janeiro a Dezembro de 2018. Foram incluídos 46 pacientes candidatos à cirurgia cardíaca eletiva e avaliados quanto ao tipo de doença cardíaca, o tipo de cirurgia, co-morbidades associadas, idade, classificação NYHA, IMC, dias de internação em UTI, avaliação da saúde bucal, ocorrência de infecção e óbito hospitalar. A análise foi feita através de análise de frequências absoluta e relativa, estimativa de odds ratio, teste de qui-quadrado e teste de Mann-Whitney. Resultados: 
Dos 46 pacientes analisados, $11(23,9 \%)$ deles tiverem infecções hospitalares e $4(8,7 \%)$ foram a óbito, não houve diferença estatisticamente significativa das variáveis estudadas com a ocorrência de infecção ou óbito hospitalar. A heterogeneidade dos achados na avaliação bucal que variou desde de pacientes edêntulos com próteses parciais ou totais, desdentados parciais com próteses ou sem próteses e graus variados de doença bucal que variou de gengivites, periodontites até abscessos. As próteses apresentavam graus variados de conservação e higiene. Esta grande variabilidade de achados pode ter implicado não significância estatística das variáveis Conclusão: Não houve diferença estatística na ocorrência de pneumonia hospitalar, mediastinite, endocardite, infecção de sítio cirúrgico e óbito hospitalar segundo a condição de saúde bucal dos pacientes.

Palavras-chave: Cirurgia torácica; Saúde bucal; Infecção hospitalar.

\section{Resumen}

Objetivo: Analizar la relación de la enfermedad oral con el riesgo de desarrollar neumonía adquirida en el hospital, mediastinitis, endocarditis, infección del sitio quirúrgico y muerte hospitalaria en pacientes sometidos a cirugías cardíacas electivas. Evaluar qué factores de riesgo estarían relacionados con el riesgo de infección hospitalaria y muerte tras las cirugías cardíacas. Metodología: Se trata de un estudio analítico, observacional y prospectivo realizado de enero a diciembre de 2018. Se incluyeron 46 pacientes candidatos a cirugía cardíaca electiva y se evaluaron el tipo de cardiopatía, el tipo de cirugía, las comorbilidades asociadas, la edad, la clasificación de la NYHA, el IMC, los días de estancia en la UCI, la evaluación de la salud oral, la aparición de infecciones y la muerte en el hospital. El análisis se realizó mediante el análisis de frecuencias absolutas y relativas, la estimación de odds ratio, la prueba de chicuadrado y la prueba de Mann-Whitney. Resultados: De los 46 pacientes analizados, 11 (23,9\%) tuvieron infecciones hospitalarias y $4(8,7 \%)$ fallecieron, no existiendo diferencias estadísticamente significativas de las variables estudiadas con la ocurrencia de infección o muerte hospitalaria. La heterogeneidad de los hallazgos en la evaluación oral que varió desde pacientes edéntulos con prótesis parcial o total, edéntulos parciales con prótesis o sin prótesis y grados variados de enfermedad oral que variaron desde gingivitis, periodontitis hasta abscesos. Las prótesis presentaban diversos grados de conservación e higiene. Esta gran variabilidad de los hallazgos puede haber implicado la no significación estadística de las variables. Conclusión: No hubo diferencias estadísticas en la aparición de neumonía hospitalaria, mediastinitis, endocarditis, infección del sitio quirúrgico y muerte hospitalaria según el estado de salud bucodental de los pacientes.

Palabras clave: Cirugía torácica; Salud bucal; Infección hospitalaria.

\section{Introduction}

Cardiovascular diseases (CVD) are among the main causes of death in women and men in Brazil. In 2016, these diseases were the cause of death for more than 360 thousand people in the country, with a predominance of males, whites and over 65 years of age (Datasus, 2019). Cardiac surgeries are in line with the treatment of these diseases, and in 2012, more than 102 million cardiac surgeries were performed (Dordetto, Pinto \& Rosa, 2016).

Patients undergoing cardiac surgery, in turn, have a higher risk of systemic infection due to multiple factors (Sabatier, Peredo \& Valles, 2009). Hospital infections, including postoperative ones, are preventable, most of the time, and have an important impact on hospital costs, increased length of hospital stay and morbidity and mortality (Gelijins et al., 2014).

Oral health affects health in general and this can be evidenced through the relationship of some systemic diseases (such as cardiovascular diseases) and some oral diseases, especially periodontal diseases (Belinga et al., 2018). We know that the inflammatory reactions generated by these diseases are not restricted to the place of origin, as microorganisms and inflammatory mediators, such as interleukin-1 (IL-1) and tumor necrosis factor alpha (TNF-alpha) can disseminate via the bloodstream, inducing systemic inflammatory reagents and the formation of serum antibodies against periodontal bacteria (Paula e Silva et al., 2010; Bansal, Khatri \& Taneja, 2013).

Given the above, several studies show the relationship between the presence of periodontitis and several systemic diseases, such as atherosclerosis, cardiovascular diseases, respiratory diseases and diabetes mellitus (Paula e Silva et al., 2010). Bacterial toxins and the long term continuous exposure to the oral bacteremia can even induce an immune response and a systemic inflammatory response that might contribute to coronary atherosclerosis and, in combination with additional risk factors, lead to coronary heart disease and /or myocardial infarction (Blanck \& Halaszynski, 2015).

However, the intraoral health condition of patients is not a preoperative concern in most hospitals (Blanck \& 
Halaszynski, 2015) for several reasons, such as: lack of knowledge of the patient about this association, lack of knowledge of surgeons of the real importance of eradicating a possible source of infection and lack of financial resources to provide adequate preoperative care (Yasny \& White, 2009).

Thus, it is necessary to search for new pre-operative interventions that might reduce the chance of appearance of postoperative infections and therefore generate increased survival, reduction of costs and improvement rates of preventable infections. Therefore, this study aims to evaluate the association between the presence of oral disease with the occurrence of nosocomial infection and death after elective cardiac surgery.

In addition, it was evaluated whether other variables such as comorbidities, type of surgery, length of stay in the intensive care unit (ICU) and NYHA classification (functional classification of the New York Heart Association), correlated with the risk of hospital infection and death after cardiac surgery.

\section{Methodology}

\subsection{Study Type}

An analytical, observational, cohort, prospective, blind study, carried out from January to December 2018 (Pereira et al, 2018). The study was carried out with 46 patients who were candidates for cardiac surgery, operated by one of the three cardiac surgeons of the same hospital team. All were informed about the nature of the research and signed the free and informed consent form in accordance with resolution 466/2012 of the National Health Council of the Ministry of Health. Data were collected from patients hospitalized at Santa Casa and at Hospital Vicentino of Ponta Grossa/PR, Brazil. This project was approved by the Research Ethics Committee of the State University of Ponta Grossa, under protocol number 2,991,272.

\subsection{Inclusion and Exclusion Criteria}

The inclusion criteria were patients who were candidates for elective cardiac surgery, who had signed the free and informed consent form and over 18 years of age.

The exclusion criteria were emergency or emergency surgeries in which there was no possibility of performing an oral health assessment.

Sampling was carried out for convenience and depended on the availability of the dental surgeon to carry out the assessment of patients' oral conditions.

\subsection{Studied Variables}

a) Heart disease: coronary regurgitation, aortic valve disease, mitral valve disease, tricuspid valve disease, aortic aneurysm.

b) Type of surgery: coronary artery bypass graft, aortic valve replacement, aortic root replacement, mitral valve replacement and tricuspid repair.

c) Comorbidities: chronic obstructive pulmonary disease (COPD), previous cardiac surgery, diabetes mellitus, depression, anxiety, pulmonary arterial hypertension, hypothyroidism, alcoholism, cardiac arrhythmia, smoking and chronic renal failure.

d) Age.

e) New York Heart Association (NYHA) functional classification (Rohde et al., 2018).

f) Body mass index (BMI), divided into: (I) normal, when between 18.5 to 24.9, (II) overweight when between 25 to 29.9, (III) grade I obesity, when between 30 at 34.9 , (IV) grade II obesity when between 35 and 39.9 , (V) grade III obesity when over 40.

g) Time of ICU stay. 
h) Presence of healthcare-related infections (HAI), which are pneumonia, endocarditis, mediastinitis and surgical site infection, diagnosed according to the criteria of National Health Surveillance Agency (ANVISA) (2017). These criteria were evaluated during hospitalization and by outpatient return 30 days after heart surgery.

i) Occurrence of hospital death in the first 30 days after cardiac surgery.

j) Oral health assessment, analyzed using an instrument to assess inflammatory / infectious conditions of the mouth evaluation of the maxilla and mandible, evaluation of the periodontal condition (gingivitis, periodontitis, periodontal risk and presence of suppuration), possible endodontic involvement, need for extraction, assessment of the cleanliness of the prosthesis, condition of the prosthesis and denture stomatitis. The clinical examination of oral health was performed by a single dental surgeon from the interdisciplinary team. All the studied variables and criteria are described in Table 1, all of which are qualitative, except number of teeth with possible endodontic involvement or with indicated extraction. It was also decided to make an assessment of quality of life related to oral health, to understand the limitations and suffering of individuals with oral disorders. The study used the instrument called Oral Health Impact Profile or OHIP (Slade, 1997).

Table 1 - Analyzed Oral Health Variables.

\begin{tabular}{|c|c|}
\hline Variable & Unit \\
\hline Upper Jaw & $\begin{array}{l}\text { 1- Toothless without prosthesis } \\
\text { 2- Toothless with total prosthesis } \\
\text { 3- Partial edentulous without prosthesis } \\
\text { 4- Partial edentulous with removable partial denture } \\
\text { 5- Partial edentulous with fixed prosthesis / implants } \\
\text { 6- Oral function maintained by the presence of most teeth / fixed prostheses / implants } \\
\text { 7- Oral function maintained by the presence of all teeth (except third molar) }\end{array}$ \\
\hline Lower Jaw & $\begin{array}{l}\text { 1- Toothless without prosthesis } \\
\text { 2- Toothless with total prosthesis } \\
\text { 3- Partial edentulous without prosthesis } \\
\text { 4- Partial edentulous with removable partial denture } \\
\text { 5- Partial edentulous with fixed prosthesis / implants } \\
\text { 6- Oral function maintained by the presence of most teeth / fixed prostheses / implants } \\
\text { 7- Oral function maintained by the presence of all teeth (except third molar) }\end{array}$ \\
\hline Gingivitis & $\begin{array}{l}\text { 1- NA } \\
\text { 2- No } \\
\text { 3- Yes: patients with presence of at least one site with bleeding on probing at the time of measuring the clinical } \\
\text { depth of the probe or } 30-60 \text { seconds after. }\end{array}$ \\
\hline Periodontitis & $\begin{array}{l}\text { 1- NA } \\
\text { 2- No } \\
\text { 3- Moderate: defined in accordance with the criteria of Page \& Eke (2007) by the presence of } \geq 2 \text { interproximal } \\
\text { sites with CLI } \geq 4 \mathrm{~mm} \text { or } \geq 2 \text { interproximal sites with PCS } \geq 5 \mathrm{~mm} \text { (in different teeth). } \\
4 \text { Advanced: of the lanyard to the criteria Page \& Eke (2007), the presence of } \geq 2 \text { interproximal sites with CLI } 6 \\
\text { mm (in different teeth) and interproximal site } \geq 1 \geq 5 \mathrm{~mm} \text { with CDP. }\end{array}$ \\
\hline Periodontal Risk & $\begin{array}{l}\text { 1- NA } \\
\text { 2- Low risk: up to } 4 \text { sites with } \mathrm{CDP} \geq 5 \mathrm{~mm} \text {. } \\
\text { 3- Medium risk: } 5 \text { to } 9 \text { sites with } \mathrm{CDP} \geq 5 \mathrm{~mm} \text {. } \\
\text { 4- High risk: } \geq 10 \text { sites with } \mathrm{CDP} \geq 5 \mathrm{~mm} \text { (Dennesen } \text { et al, 2003). }\end{array}$ \\
\hline $\begin{array}{l}\text { Possible Endodontic } \\
\text { Involvement or with } \\
\text { Extraction Indicated }\end{array}$ & Number of marked teeth \\
\hline Prosthesis Removal & $\begin{array}{l}\text { 1- Did not remove it } \\
\text { 2- Removed it, but did not immerse it into anything } \\
\text { 3- Immersed it into water } \\
\text { 4- Immersed it into a solution }\end{array}$ \\
\hline Prosthesis Cleaning & $\begin{array}{l}\text { 1- No visible plate on the prosthesis } \\
\text { 2- Visible scraping plate }\end{array}$ \\
\hline
\end{tabular}




\begin{tabular}{|c|c|}
\hline & $\begin{array}{l}\text { 3- Visible plate without scraping } \\
\text { 4- Defined plate } \\
\text { 5- Plate with velvety appearance }\end{array}$ \\
\hline Prosthesis Condition & $\begin{array}{l}\text { 1- Excellent clinical status } \\
\text { 2- Acceptable clinical status } \\
\text { 3- Prosthesis needs repair or modification to prevent damage to the patient } \\
\text { 4- Prosthesis has serious defects, produces damage to the patient and needs immediate repair or modification }\end{array}$ \\
\hline Denture Stomatitis (ED) & $\begin{array}{l}\text { Classified according to Newton (1962) in: } \\
\text { 1- Type I: localized hyperemic lesions (simple localized inflammation). } \\
\text { 2- Type II: diffuse erythema confined to contact with the prosthesis (generalized simple inflammation). } \\
\text { 3- Type III: presence of hyperemic mucosa associated with the granular surface (inflammatory hyperplasia of the } \\
\text { palate) }\end{array}$ \\
\hline Heart disease (CD) & $\begin{array}{l}\text { 1- Aortic stenosis } \\
\text { 2- Ascending aortic aneurysm } \\
\text { 3- Severe aortic regurgitation } \\
\text { 4- Coronary artery disease } \\
\text { 5- Marked tricuspid regurgitation } \\
\text { 6- Bicuspid aortic valve } \\
\text { 7- Mitral stenosis } \\
\text { 8- Mitral regurgitation }\end{array}$ \\
\hline Comorbidities & $\begin{array}{l}\text { 1- None } \\
\text { 2- Chronic Obstructive Pulmonary Disease (COPD) } \\
\text { 3- Previous Cardiac Surgery } \\
\text { 4- Diabetes mellitus (DM) } \\
\text { 5- Depression / anxiety } \\
\text { 6- Pulmonary arterial hypertension (PAH) } \\
\text { 7- Hypothyroidism } \\
\text { 8- Alcoholism } \\
\text { 9- Arrhythmia } \\
\text { 10- Smoking } \\
\text { 11- Chronic kidney disease }\end{array}$ \\
\hline NYHA & $\begin{array}{l}\text { 1- No symptoms and no limitations in routine activities; more than } 6 \text { METs in ergometry. } \\
\text { 2- Mild symptoms and limitations in routine activities. Comfortable at rest (dyspnea on habitual exertion). From } \\
4 \text { to } 6 \text { METs in ergometry. } \\
\text { 3- With significant limitation in physical activity; smaller than routine activities produce symptoms. } \\
\text { Comfortable only at rest (dyspnea on exertion less than usual). 2-4 METs in ergometry. } \\
\text { 4- Severe limitations. Symptoms present even at rest. It does not tolerate ergometry. }\end{array}$ \\
\hline Type of surgery & $\begin{array}{l}\text { 1- Aortic valve replacement } \\
\text { 2- Exchange of aortic root } \\
\text { 3- Coronary artery bypass graft } \\
\text { 4- Mitral valve replacement } \\
\text { 5- Tricuspid plasty }\end{array}$ \\
\hline Infection & $\begin{array}{l}\text { 1- Yes } \\
\text { 2- No }\end{array}$ \\
\hline Type of infection & $\begin{array}{l}\text { 1- NA } \\
\text { 2- Pneumonia } \\
\text { 3- Surgical site infection } \\
\text { 4- Mediastinitis } \\
\text { 5- Endocarditis }\end{array}$ \\
\hline Outcome / death & $\begin{array}{l}\text { 1- Yes } \\
\text { 2- No }\end{array}$ \\
\hline
\end{tabular}

Notes: NA: not applicable; NYHA: New York Heart Association functional classification; MET: metabolic equivalent; CDP: clinical depth of the probe; CLI: clinical level of periodontal insertion. Source: Authors. 


\subsection{Statistical Analysis}

Initially, we proceeded the analysis of the descriptive data to estimate frequency of all qualitative variables. Then, we verified the frequencies related to the occurrence of infection and the occurrence of death with an odds ratio (OR) estimate with a 95\% confidence interval (CI) and the chi-square test.

Finally, we verified the adherence of the quantitative variables to the normal distribution by the Shapiro-Wilk test and all did not have a normal distribution, therefore, to verify their differences between the groups with and without infection and with death and without death, we performed the Mann-Whitney U test. The tests were considered significant when $\mathrm{p}<0.05$ and the analyzes were performed using SPSS 21.0 (IBM, 2012).

\section{Results}

The age of the patients analyzed ranged from 35 to 86 years, with an average of 65 years. Of the 46 patients analyzed, $11(23.9 \%)$ of them had hospital infections and $4(8.7 \%)$ died (Table 1). Regarding the heart diseases that motivated the surgery, coronary artery disease (CAD) was the most common and, consequently, the majority of patients underwent coronary artery bypass graft surgery. In reference to comorbidities, the most common was diabetes mellitus (DM) present in $34.8 \%$ of cases. Mood disorders such as anxiety and depression were also common (Table 2).

Table 2 - Patient profile, postoperative infections and type of surgery.

\begin{tabular}{lc}
\hline \multicolumn{2}{c}{ Infection / Death } \\
\hline None & $35(76.1 \%)$ \\
\hline Pneumonia & $7(15.2 \%)$ \\
\hline Surgical site infection & $4(8.7 \%)$ \\
\hline Mediastinitis & $0(0 \%)$ \\
\hline Endocarditis & $0(0 \%)$ \\
\hline Total infections & $11(23.9 \%$ \\
\hline Deaths & $4(8.7 \%)$ \\
\hline
\end{tabular}

Source: Authors.

Table 3 - Profile of patients regarding heart disease, type of surgery and comorbidities.

\begin{tabular}{lclclc}
\hline \multicolumn{1}{c}{ Heart disease } & \multicolumn{2}{c}{ Type of Surgery } & \multicolumn{2}{c}{ Comorbidities } \\
\hline CAD & $28(60.9 \%)$ & CABG & $24(52.1 \%)$ & DM & $16(34.8 \%)$ \\
\hline Aortic stenosis & $10(21.7 \%)$ & AVR & $11(23.9 \%)$ & None & $10(21.7 \%)$ \\
\hline Aortic regurgitation & $6(13 \%)$ & CABG + AVR & $4(8.7 \%)$ & Depression / anxiety & $12(26.1 \%)$ \\
\hline Mitral stenosis & $3(6.5 \%)$ & MVR + VT plasty & $2(4.36 \%)$ & $\begin{array}{l}\text { Previous cardiac } \\
\text { surgery }\end{array}$ & $11(23.9 \%)$ \\
\hline Ascending aortic aneurysm & $2(4.3 \%)$ & MVR & $2(4.36 \%)$ & COPD & $5(10.9 \%)$ \\
\hline Mitral regurgitation & $1(2.2 \%)$ & ARR & $2(4.36 \%)$ & Smoking & $4(8.7 \%)$ \\
\hline Tricuspid regurgitation & $1(2.2 \%)$ & CABG + MVR & $1(2.2 \%)$ & Hypothyroidism & $3(6.5 \%)$ \\
\hline Bicuspid aortic valve & $1(2.2 \%)$ & Total & $46(100 \%)$ & Arrhythmia & $3(6.5 \%)$ \\
\hline & & & PAH & Alcoholism & $1(2.2 \%)$ \\
\hline & & & CKD & $1(2.2 \%)$ \\
\hline
\end{tabular}

Notes: Total comorbidities add up to more than $100 \%$ of patients, as there were patients with more than one comorbidities. Abbreviations: ARR: aortic root replacement; AVR: aortic valve replacement; CABG: coronary artery bypass graft; CAD: coronary artery disease; CKD: chronic kidney disease; COPD: chronic obstructive pulmonary disease; DM: diabetes mellitus; MVR: mitral valve replacement; PAH: pulmonary artery hypertension; TV: tricuspid valve. Source: Authors. 
With regard to the NYHA classification, 8 patients $(17.4 \%)$ had no limitations in routine activities and most patients $(82.6 \%)$ had some type of limitation - NYHA 2, 3 or 4.

Regarding the body mass index (BMI) of the patients evaluated, it was observed that 8 patients $(17.4 \%)$ were in the healthy classification, 19 patients $(41.3 \%)$ were overweight, 18 patients $(39,1 \%)$ were considered grade 1 obese and only 1 patient $(2,2 \%)$ was considered grade 2 obese .

As for the ICU time after cardiac surgery, the average was 4.5 days, with a maximum of 26 days (1 patient) and a minimum of 2 days (6 patients).

Regarding the Oral Evaluation, the questionnaire on quality of life (OHIP-14) obtained an average of 6.6 points, which demonstrated that the quality of life of the oral health of the patients analyzed was not bad. The other results are described in Table 4.

Table 4 - Description of the results of the Oral Assessment.

\begin{tabular}{|c|c|c|c|}
\hline Variable & Criterion & $\mathbf{N}^{\circ}$ & $\%$ \\
\hline \multirow[t]{3}{*}{ Number of Teeth } & Edentulous without prosthesis & 0 & 0 \\
\hline & Edentulous, but with at least 1 total prosthesis & 18 & 39.1 \\
\hline & Patients with one or more teeth & 28 & 60.9 \\
\hline \multirow[t]{6}{*}{ Upper Jaw } & Toothless without prosthesis & 2 & 4.3 \\
\hline & Toothless with full denture & 27 & 58.7 \\
\hline & Partial toothless without prosthesis & 2 & 4.3 \\
\hline & Partial edentulous with removable partial dentures & 4 & 8.7 \\
\hline & Oral function maintained by the presence of most teeth & 10 & 21.7 \\
\hline & Oral function maintained by the presence of all teeth & 1 & 2.2 \\
\hline \multirow{6}{*}{ Lower Jaw } & Toothless without prosthesis & 4 & 8.7 \\
\hline & Toothless with full denture & 14 & 30.4 \\
\hline & Partial toothless without prosthesis & 6 & 13.0 \\
\hline & Partial edentulous with removable partial denture & 5 & 10.9 \\
\hline & Oral function maintained by the presence of most teeth & 15 & 32.6 \\
\hline & Oral function maintained by the presence of all teeth & 2 & 4.3 \\
\hline \multirow{2}{*}{ Gingivitis } & Yes & 22 & 78.6 \\
\hline & No & 6 & 22.3 \\
\hline \multirow{3}{*}{ Periodontitis } & Moderate periodontitis & 19 & 67.9 \\
\hline & Severe periodontitis & 1 & 3.5 \\
\hline & Without periodontitis & 8 & 28.6 \\
\hline \multirow[t]{3}{*}{ Periodontal risk } & Low & 13 & 28.3 \\
\hline & Moderate & 12 & 26.1 \\
\hline & High & 3 & 6.5 \\
\hline \multirow[t]{2}{*}{ Suppurated teeth } & Yes & 1 & 2.2 \\
\hline & No & 27 & 97.8 \\
\hline $\begin{array}{l}\text { Teeth with possible endodontic involvement } \\
\text { or indication for extraction }\end{array}$ & Average of 1.8 teeth & 14 & $30.4 \%$ \\
\hline \multirow[t]{2}{*}{ Prosthesis use time } & Average use of upper dentures: 22.5 years & 31 & - \\
\hline & Average use of lower dentures: 24.3 years & 21 & - \\
\hline \multirow[t]{2}{*}{ Removing the prosthesis while sleeping } & Yes & 3 & 9.1 \\
\hline & No & 30 & 90.9 \\
\hline \multirow[t]{5}{*}{ Prosthesis cleaning } & They had no visible plaque on the prosthesis & 11 & 33.3 \\
\hline & Visible scraping plate & 2 & 6.1 \\
\hline & Visible plate without scraping & 11 & 33.3 \\
\hline & Plate defined under the prosthesis & 3 & 9.1 \\
\hline & Velvety plate on the prosthesis & 6 & 18.2 \\
\hline \multirow[t]{4}{*}{ Prosthesis condition } & Great & 5 & 15.2 \\
\hline & Acceptable & 13 & 39.4 \\
\hline & Need for repairs & 10 & 30.3 \\
\hline & Serious defects in the prosthesis & 5 & 15.2 \\
\hline \multirow[t]{4}{*}{ Denture stomatitis } & No stomatitis & 27 & 58.7 \\
\hline & Grade I stomatitis & 14 & 30.4 \\
\hline & Grade II stomatitis & 5 & 10.9 \\
\hline & Grade III stomatitis & 0 & 0 \\
\hline OHIP-14 & Average of 6.6 points & - & - \\
\hline
\end{tabular}

Notes: The variables gingivitis, periodontitis, periodontal risk, suppurated teeth and teeth with possible endodontic involvement or indication of tooth extraction were evaluated only among the 28 patients with teeth. Source: Authors. 
As for heart disease and surgery, there was no statistical difference in relation to the occurrence of hospital infection or death. The same occurred when comparing variables with morbidities, NYHA and BMI (Table 5).

Table 5 - Analysis of cardiac diseases and surgeries, comorbidities, NYHA, BMI and the occurrence of hospital infection and death.

\begin{tabular}{|c|c|c|c|c|c|c|c|c|}
\hline \multirow[b]{2}{*}{ Heart disease } & \multicolumn{4}{|c|}{ Infection } & \multicolumn{4}{|c|}{ Death } \\
\hline & $\begin{array}{c}\text { With } \\
\text { infection }\end{array}$ & $\begin{array}{c}\text { No } \\
\text { infection }\end{array}$ & OR $(95 \% \mathrm{CI})$ & $\mathbf{p}$ & Death & Discharge & (OR 95\% CI) & $\mathbf{P}$ \\
\hline Aortic stenosis & $4(40 \%)$ & $6(60 \%)$ & $\begin{array}{c}2.76 \\
(0.61-12.51)\end{array}$ & 0.175 & $0(0 \%)$ & $10(100 \%)$ & - & 0.361 \\
\hline $\begin{array}{l}\text { Ascending aortic } \\
\text { aneurysm }\end{array}$ & $0(0 \%)$ & $2(100 \%)$ & - & 0.575 & $1(50 \%)$ & $1(50 \%)$ & $\begin{array}{c}13.67 \\
(0.67-277.12)\end{array}$ & 0.168 \\
\hline Aortic regurgitation & $1(16.7 \%)$ & $5(83.3 \%)$ & $\begin{array}{c}0.6 \\
(0.06-5.77)\end{array}$ & 0.555 & $1(16.7 \%)$ & $5(83.3 \%)$ & $\begin{array}{c}2.47 \\
(0.21-28.53)\end{array}$ & 0.44 \\
\hline Coronary artery disease & $5(17.9 \%)$ & $23(82.1 \%)$ & $\begin{array}{c}0.43 \\
(0.11-1.72)\end{array}$ & 0.198 & $2(7.1 \%)$ & $26(92.9 \%)$ & $\begin{array}{c}0.61 \\
(0.08-4.81)\end{array}$ & 0.513 \\
\hline Tricuspid regurgitation & $0(0 \%)$ & $1(100 \%)$ & - & 0.761 & $0(0 \%)$ & $1(100 \%)$ & - & 0.913 \\
\hline Bicuspid aortic valve & $0(0 \%)$ & $1(100 \%)$ & - & 0.761 & $0(0 \%)$ & $1(100 \%)$ & - & 0.913 \\
\hline Mitral stenosis & $2(66.7 \%)$ & $1(33.3 \%)$ & $\begin{array}{c}7.56 \\
(0.61-93.01)\end{array}$ & 0.138 & $1(33.3 \%)$ & $2(66.7 \%)$ & $\begin{array}{c}6.67 \\
(0.46-96.44) \\
\end{array}$ & 0.244 \\
\hline Mitral regurgitation & $0(0 \%)$ & $1(100 \%)$ & - & 0.761 & $0(0 \%)$ & $1(100 \%)$ & - & 0.913 \\
\hline Type of Surgery & $\begin{array}{c}\text { With } \\
\text { infection }\end{array}$ & $\begin{array}{c}\text { No } \\
\text { infection }\end{array}$ & OR $(95 \% \mathrm{CI})$ & $\mathbf{p}$ & Death & Discharge & (OR 95\% CI) & $\mathbf{P}$ \\
\hline AVR & $4(26.7 \%)$ & $11(73.3 \%)$ & $\begin{array}{c}1.25(0.3- \\
5.16)\end{array}$ & 0.516 & $0(0 \%)$ & $15(100 \%)$ & - & 0.193 \\
\hline ARR & $1(50 \%)$ & $1(50 \%)$ & $\begin{array}{c}3.4(0.19- \\
59.37)\end{array}$ & 0.425 & $1(50 \%)$ & $1(50 \%)$ & $\begin{array}{c}13.67(0.67- \\
277.12)\end{array}$ & 0.168 \\
\hline CABG & $5(17.2 \%)$ & $24(82.8 \%)$ & $\begin{array}{c}0.38(0.09- \\
1.52)\end{array}$ & 0.152 & $2(6.9 \%)$ & $27(93.1 \%)$ & $0.56(0.07-4.35)$ & 0.474 \\
\hline MVT & $2(40 \%)$ & $3(60 \%)$ & $\begin{array}{c}2.37(0.34- \\
16.43)\end{array}$ & 0.343 & $1(20 \%)$ & $4(80 \%)$ & $\begin{array}{c}3.17(0.26- \\
38.07)\end{array}$ & 0.379 \\
\hline TV plasty & $1(33.3 \%)$ & $2(66.7 \%)$ & $\begin{array}{l}1.65(0.13- \\
20.15)\end{array}$ & 0.569 & $0(0 \%)$ & $3(100 \%)$ & - & 0.756 \\
\hline Variable & $\begin{array}{c}\text { With } \\
\text { infection }\end{array}$ & $\begin{array}{c}\text { No } \\
\text { infection }\end{array}$ & OR $(95 \% \mathrm{CI})$ & $\mathbf{p}$ & Death & Discharge & (OR 95\% CI) & $\mathrm{P}$ \\
\hline Comorbidities & $10(27.8 \%)$ & $26(72.2 \%)$ & $\begin{array}{c}3.46(0.39- \\
30.96)\end{array}$ & 0.236 & $3(8.3 \%)$ & $33(91.7 \%)$ & $0.82(0.08-8.84)$ & 0.639 \\
\hline NYHA with limitations & $11(28.9 \%)$ & $27(71.1 \%)$ & - & 0.091 & $3(7.9 \%)$ & $35(92.1 \%)$ & $0.6(0.05-6.64)$ & 0.548 \\
\hline BMI- Healthy & $5(27.8 \%)$ & $13(72.2 \%)$ & & & $2(11.1 \%)$ & $16(88.9 \%)$ & & \\
\hline Overweight & $0(0 \%)$ & $1(100 \%)$ & & 0907 & $0(0 \%)$ & $1(100 \%)$ & & 784 \\
\hline Grade I obesity & $2(25 \%)$ & $6(75 \%)$ & & & $0(0 \%)$ & $8(100 \%)$ & & \\
\hline Grade II obesity & $4(21.1 \%)$ & $15(78.9 \%)$ & & & $2(10.5 \%)$ & $17(87.5 \%)$ & & \\
\hline
\end{tabular}

Abbreviations: ARR: aortic root replacement; AVR: aortic valve replacement; BMI: body mass index; CABG: coronary artery bypass graft; MVR: mitral valve replacement; NYHA: New York Heart Association Functional Classification;TV: tricuspid valve. Source: Authors.

Regarding the oral evaluation, the variables of number of teeth, time of use of upper denture, time of use of lower denture and presence of oral lesions due to the use of prosthesis, comparing them with the presence of hospital infection and death, there was no significant difference (Table 6). 
Table 6 - Number of teeth, time of use of upper denture, time of use of lower denture, presence of oral lesions due to the use of prostheses and the occurrence of hospital infection and death.

\begin{tabular}{lcccccccccc}
\hline & \multicolumn{4}{c}{ Infection } & \multicolumn{3}{c}{ Death } \\
\hline & With infection & No infection & p & Death & \multicolumn{2}{c}{ Discharge } & P \\
\hline & Mean & DP & Mean & DP & & Mean & DP & Mean & DP \\
\hline Number of teeth & 7 & 9 & 9 & 10 & 0.666 & 13 & 11 & 8 & 10 & 0.51 \\
\hline Time of use of upper denture & 26 & 19 & 23 & 16 & 0.749 & 9 & 2 & 25 & 17 & 0.241 \\
\hline Lower denture usage time & 18 & 14 & 26 & 17 & 0.445 & 13 & 4 & 26 & 17 & 0.467 \\
\hline Number of frames & 5 & 5 & 6 & 9 & 0.867 & 1 & 2 & 6 & 8 & 0.38 \\
\hline
\end{tabular}

Source: Authors.

In comparison with the other variables of the oral analysis, such as the presence of teeth, gingivitis, periodontitis, periodontal risk, presence of suppuration and endodontic involvement, there was no statistical difference related to the occurrence of infection or death. Regarding the removal or not of prosthesis at bedtime, cleaning of the prosthesis, condition of the prosthesis, degree of stomatitis and occurrence of hospital infection or death, the results also did not show statistical difference (Table 7).

Table 7 - Analysis of the presence of teeth, gingivitis, degree of periodontitis, presence of suppuration, endodontic involvement, care with the prosthesis (cleaning, removal, condition) and stomatitis with the presence of hospital infection and death.

\begin{tabular}{|c|c|c|c|c|c|c|c|c|c|}
\hline \multirow[b]{2}{*}{ Variable } & \multirow[b]{2}{*}{ Category } & \multicolumn{4}{|c|}{ Infection } & \multicolumn{4}{|c|}{ Death } \\
\hline & & $\begin{array}{c}\text { With } \\
\text { Infection }\end{array}$ & No Infection & $\begin{array}{c}\text { OR }(95 \% \\
\text { CI) }\end{array}$ & p & Death & Discharge & $\begin{array}{c}\text { OR }(95 \% \\
\text { CI })\end{array}$ & p \\
\hline $\begin{array}{l}\text { Presence of } \\
\text { teeth }\end{array}$ & Yes & $6(21.4 \%)$ & $22(78.6 \%)$ & $\begin{array}{c}0.71(0.18- \\
2.79)\end{array}$ & 0.44 & $3(10.7 \%)$ & $25(89.3 \%)$ & $\begin{array}{c}2.04(0.19- \\
21.29)\end{array}$ & 0.477 \\
\hline Gingivitis & Yes & $5(22.7 \%)$ & $17(77.3 \%)$ & $\begin{array}{c}1.47(0.14- \\
15.69)\end{array}$ & 0.617 & $2(9.1 \%)$ & $20(90.9 \%)$ & $\begin{array}{c}0.5(0.04- \\
6.68)\end{array}$ & 0.53 \\
\hline \multirow[t]{4}{*}{ Periodontitis } & NA & $5(27.8 \%)$ & $13(72.2 \%)$ & \multirow{4}{*}{ 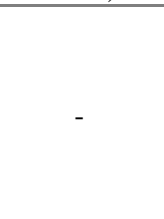 } & \multirow{4}{*}{0.778} & $1(5.6 \%)$ & $17(94.4 \%)$ & \multirow{4}{*}{ - } & \multirow{4}{*}{0.909} \\
\hline & No & $1(12.5 \%)$ & $7(87.5 \%)$ & & & $1(12.5 \%)$ & $7(87.5 \%)$ & & \\
\hline & Moderate & $5(26.5 \%)$ & $14(73.7 \%)$ & & & $2(10.5 \%)$ & $17(89.5 \%)$ & & \\
\hline & Advanced & $0(0 \%)$ & $1(100 \%)$ & & & $0(0 \%)$ & $1(100 \%)$ & & \\
\hline \multirow{4}{*}{$\begin{array}{l}\text { Periodontal } \\
\text { risk }\end{array}$} & NA & $5(27.8 \%)$ & $13(72.2 \%)$ & \multirow{4}{*}{-} & \multirow{4}{*}{0.533} & $1(5.6 \%)$ & $17(94.4 \%)$ & \multirow{4}{*}{ - } & \multirow{4}{*}{0.124} \\
\hline & Low & $2(15.4 \%)$ & $11(84.6 \%)$ & & & $0(0 \%)$ & $13(100 \%)$ & & \\
\hline & Average & $4(33.3 \%)$ & $8(66.7 \%)$ & & & $3(25 \%)$ & $9(75 \%)$ & & \\
\hline & High & $0(0 \%)$ & $3(100 \%)$ & & & $0(0 \%)$ & $3(100 \%)$ & & \\
\hline Suppuration & Yes & $0(0 \%)$ & $1(100 \%)$ & - & 0.761 & $0(0 \%)$ & $1(100 \%)$ & - & 0.913 \\
\hline $\begin{array}{l}\text { Endodontic } \\
\text { involvement }\end{array}$ & Yes & $3(21.4 \%)$ & $11(78.6 \%)$ & $\begin{array}{c}0.82(0.18- \\
3.69)\end{array}$ & 0.556 & $0(0 \%)$ & $14(100 \%)$ & - & 0.22 \\
\hline $\begin{array}{l}\text { Prosthesis } \\
\text { removal }\end{array}$ & Yes & $0(0 \%)$ & $3(100 \%)$ & - & 0.325 & $0(0 \%)$ & $3(100 \%)$ & - & 0.744 \\
\hline $\begin{array}{l}\text { Prosthesis } \\
\text { cleaning }\end{array}$ & With plate & $8(36.4 \%)$ & $14(63.6 \%)$ & $\begin{array}{c}2.57(0.44- \\
14.97)\end{array}$ & 0.256 & $2(9.1 \%)$ & $20(90.9 \%)$ & $\begin{array}{c}1.00(0.08- \\
12.40)\end{array}$ & 0.718 \\
\hline $\begin{array}{l}\text { Prosthesis } \\
\text { condition }\end{array}$ & $\begin{array}{l}\text { Needs } \\
\text { repairs or } \\
\text { serious } \\
\text { damage }\end{array}$ & $3(20 \%)$ & $12(80 \%)$ & 0.39 & 0.214 & $1(6.7 \%)$ & $14(93.3 \%)$ & $\begin{array}{c}0.57(0.05- \\
7.00)\end{array}$ & 0.57 \\
\hline \multirow[t]{2}{*}{ Stomatitis } & Type 1 & $5(35.7 \%)$ & $9(64.3 \%)$ & \multirow[b]{2}{*}{ - } & \multirow{2}{*}{0.462} & $2(14.3 \%)$ & $12(85.7 \%)$ & \multirow[b]{2}{*}{ - } & \multirow{2}{*}{0.582} \\
\hline & Type 2 & $1(20 \%)$ & $4(80 \%)$ & & & $0(0 \%)$ & $5(100 \%)$ & & \\
\hline
\end{tabular}

Note: NA: not applicable. Source: Authors. 
When comparing the variables of quality of life, age of patients and number of days in the ICU with the presence or absence of infection or death, there was no statistically significant difference (Table 8).

Table 8 - Comparison of the variables of quality of life, age of the patient and number of days in the ICU with the presence of hospital infection and deaths.

\begin{tabular}{lcccccccccc}
\hline & \multicolumn{4}{c}{ Infection } & \multicolumn{5}{c}{ Deaths } \\
\hline \multicolumn{1}{c}{ Variable } & $\begin{array}{c}\text { With } \\
\text { infection }\end{array}$ & No Infection & $\mathbf{p}$ & Death & Discharge & p \\
& Mean & DP & Mean & DP & & Mean & DP & Mean & DP \\
\hline Quality of life & 5 & 5 & 7 & 9 & 0.96 & 3 & 6 & 7 & 8 & 0.2 \\
\hline Patient's age & 64 & 9 & 65 & 11 & 0.764 & 64 & 9 & 65 & 10 & 0.747 \\
\hline Number of days in ICU & 7 & 7 & 4 & 2 & 0.233 & 5 & 5 & 4 & 4 & 0.631
\end{tabular}

Note: ICU: Intensive Care Unit. Source: Authors.

\section{Discussion}

This study evaluated 46 patients with the objective of evaluating the impact of oral health on the occurrence of infections and death in the postoperative period of cardiac surgery and did not find a significant result for the studied variables or for other clinical variables included in the research. It is worth mentioning the heterogeneity of the findings in the oral evaluation that ranged from edentulous patients with partial or total dentures, partial edentulous with or without prosthesis and varying degrees of oral disease that ranged from gingivitis, periodontitis to abscesses. The prostheses had varying degrees of conservation and hygiene. This great variability of findings may have implied no statistical significance for the variables. A sample significantly larger than this could find relationships between oral disease and infections or death. Nevertheless, the study has value for which can be a material with important and useful data for future meta-analysis, as the collection and evaluation of data was thorough and followed a strict scientific standard.

With regard to ISC rates, a 4-year retrospective study carried out at a University Hospital in Minas Gerais, Brazil, found a rate of 18.6\% (Braz, Evangelista, Evangelista, Garbaccio \& Oliveira, 2018), another retrospective study carried out in several French institutions (Cossin et al., 2018) found an ISC rate of $1.9 \%$ to $2.5 \%$ in 4 years. This demonstrates that the ISC rates can vary widely from region to region and that the one found in this study is within the expected value.

Regarding the NYHA classification, a prospective study conducted in Florianópolis - Santa Catarina, Brazil, (Cani et al., 2015) with patients undergoing cardiac surgery found that $35.4 \%$ of the 48 patients analyzed, had no limitation in routine activities, which suggests that in our study, patients were more severe and symptomatic, in which only $17.4 \%$ of patients had no limitation in routine activities.

The average number of ICU days found in the study ( 4.5 days) is similar to the study carried out by Laizo and collaborators, who found that of the 85 patients who underwent cardiac surgery, the length of stay in the ICU was 1 to 21 days, with average of 4.16 days.

In the study of oral assessment in the preoperative period of cardiac surgery by Bergan, Tura \& Lamas (2014), 36.6\% of the patients were edentulous, a rate that is similar to that found in the present study, which was $39.1 \%$.

Of the 28 patients who were not edentulous, $78 \%$ were diagnosed with gingivitis and 20 patients $(71.4 \%)$ were diagnosed with periodontitis and 1 patient (3.5\%) with severe periodontitis. A study published in 2013 found a prevalence of $15.3 \%$ for moderate periodontal disease and $5.8 \%$ for severe condition (Vettore, Marques \& Peres, 2013), which differs greatly from the prevalence of our study. 
Regarding the use of the OHIP-14 questionnaire, it is observed that despite the poor oral condition found in the study, with a high rate of edentulous and high prevalence of periodontitis, the patients' self-perceived oral health was not bad. This can be explained by the low health literacy of our Brazilian population, associated with less ability to understand how to prevent diseases and promote health (Quemelo, Milani, Bento, Vieira \& Zaia, 2017). It is clear that even with the precariousness of the dentition found, the patients' perception of themselves can be considered impaired. The poor oral health that we found also reflects a poor public health policy, in which dental condition is not a priority in the country's health actions.

Given the studies that relate periodontitis to cardiovascular diseases and postoperative infections, this study had an important limitation because the number of patients who presented this type of oral disease was small (20 patients). This could justify the result found, where there was no significant association with any oral disease and especially periodontitis and gingivitis with the analyzed outcomes.

In addition, almost half of the patients analyzed were edentulous, but unfortunately, the cause of this condition is not known. This can be associated with the socioeconomic condition of the population studied. The high rates of dental mutilation and edentulism, according to the literature, have dental caries and periodontal disease as the main determining factors (Batista, 2010). The socioeconomic condition of our country, associated with periodontal causes, the presence of plaques and cavities contribute to the high rates of edentulism in Brazil.

In the study conducted in the city of Rio de Janeiro, Brazil, the presence of plaques on the tongue and poor hygiene of the total upper prostheses in the preoperative period of cardiac surgeries significantly increased the chance of postoperative pneumonia ( Bergan, Tura \& Lamas , 2014), which demonstrates that despite the absence of teeth, care with oral hygiene and preoperative evaluation is essential, despite the result found in our study. This study used indexes for oral evaluation such as DMFT (index of full teeth), OHI-S (simplified oral hygiene index) and CPITN (Community periodontal index of treatment needs) and all patients were evaluated only by a single dental surgeon. .A systematic review published in 2017 (Cotti et al.) Assessed whether there was a consensus on perioperative dental screening and management of patients undergoing cardiothoracic, vascular and other invasive cardiovascular procedures. Cotti et al. (2017) observed that there is still no consensus on the need for dental care before invasive cardiovascular procedures.

This work has limitations, due to the small number of individuals evaluated due to the small amount of time for data collection. In addition, the oral assessment of all patients was performed by a single dentist, which may have been a limiting factor because some points were assessed subjectively. On the other hand, the evaluation carried out by a single person suggests a standardization of care and evaluations.

In addition, the evaluation of the oral condition was performed only with a clinical examination. The periapical radiography of all patients would assist in a more objective assessment of the cases. Unfortunately, due to the patients' financial condition and the preoperative in-hospital evaluation, it was not possible to perform the complementary examination.

It is important to emphasize that the preoperative measures indicated by Anvisa (Brasil, 2017) were all performed in all patients: $2 \%$ chlorhexidine bath before surgery, $0.12 \%$ chlorhexidine gargle before orotracheal intubation and prophylactic cefazoline before surgical incision.

It is observed that most of the studies analyzed associate cardiovascular diseases and the occurrence of respiratory diseases (in surgical postoperative periods or not) exclusively with periodontal diseases, which makes us question whether other oral diseases are relevant for future studies and whether other sources of postoperative infection are related to the disease.

New studies are suggested with a greater number of individuals evaluated so that the relationship between oral health and postoperative outcomes is analyzed, or further studies only with the selection of patients with teeth and evaluation of periodontal diseases to associate the proposed outcomes or exclusively with the occurrence of hospital pneumonia in the postoperative period of cardiac surgery. 
A study with the exclusive evaluation of periodontal disease and the relationship between periodontitis and the incidence of pneumonia in the postoperative period can provide more relevant data for future planning for the prevention of postoperative infection.

In addition, despite the results found, public health actions aimed at improving oral health could improve the quality of life of patients, decrease the risk of cardiovascular diseases and, thus, reduce the morbidity and mortality resulting from these diseases.

\section{Conclusion}

Oral condition was not a determinant of hospital infection and death after elective cardiac surgery.

There was no statistical difference between patients with oral disease and the occurrence of nosocomial pneumonia, mediastinitis, endocarditis and surgical site infection. In addition, there was also no difference in relation to other variables such as age, body mass index, presence of comorbidities, NYHA classification, days of ICU stay and type of cardiac surgery with the occurrence of hospital infection and hospital death.

\section{References}

Bansal, M., Khatri, M. \& Taneja, V. (2013). Potential role of periodontal infection in respiratory diseases - a review. Journal of medicine and life, 6 (3), 244248.

Bactor, M. J. (2010). Reasons for tooth loss in economically active adults. Dissertation (Master in Dentistry) - Faculty of Dentistry of Piracicaba, State University of Campinas. Campinas.

Belinga, L. E. E., Ngan, W. E., Lemougoum, D., Nlo'o, A. S. P. E., Bongue, B., Ngono, A., Mandengue, S. H. \& Sembene, M. (2018). Association between periodontal diseases and cardiovascular diseases in Cameroon. Journal of Public Health in Africa, 9 (1), 70-73.

Bergan, E. H., Tura, B. R. \& Lamas, C. C. (2014). Impact of improvement in preoperative oral health on nosocomial pneumonia in a group of cardiac surgery patients: a single arm prospective intervention study. Intensive Care Medicine, 40 (1), 23-3.

Blanck, N. \& Halaszynski, T. M. (2015). Intraoral infection and oral health in the surgical patient: need for concern during the perioperative period? Connecticut medicine, 79 (1), 19-25, 2015.

Brazil. National Health Surveillance Agency (2017). Health Care-Related Infection Prevention Measures. Anvisa.

Department of Informatics of SUS (DATASUS). Health Information, General Mortality. < http://www2.datasus.gov.br/DATASUS/index.php?area=0205\&id= 6937\&VObj=http://tabnet.datasus.gov.br/cgi/deftohtm.exe?sim/cnv/ obt10 >

Braz, N. J., Evangelist, S. S., Evangelist, S. S., Garbaccio, J. L. \& Oliveira, A. C. (2018). Surgical site infection in patients undergoing cardiac surgery: an analysis of the epidemiological profile. Nursing Journal of the Midwest Mineiro, 8, 1-9.

Poodle, K. C., Araujo, P. L. C., Karloh, M., of Alexandria, H. F. D., Palu, M., Rojas, D. B. \& Bonorino, K. C . (2015). Clinical characteristics of patients undergoing coronary artery bypass graft surgery. ASSOBRAFIR Science, 6 (3), 43-54.

Cossin, S., Malavaud, S., Jarno, P., Giard, M., L 'Hériteau, F., Simon, L., Bieler, L., Molinier, L., Marcheix, B. \& Venier, A. G. (2015). Surgical site infection after valvular or coronary artery bypass surgery: 2008-2011 French national SSI-RAISIN surveillance. The Journal of Hospital Infection, 91 (3), 225 -230.

Cotti, E., Arrica, M., Di Lenarda, A., Serri, S. B., Bassareo, P., Padeletti L. \& Mercuro, G. (2017). The perioperative dental screening and management of patients undergoing cardiothoracic, vascular surgery and other cardiovascular invasive procedures: A systematic review. European Journal of Preventive Cardiology, 24 (4), 409-425.

Dennesen, P. , van der Ven, A., Vlasveld, M., Lokker, L., Ramsay, G., Kessels, A., van den Keijbus, P., Amerongen, A. N. \& Veerman, E. (2003). Inadequate salivary flow and poor oral mucosal status in intubated intensive care unit patients. Critical Care Medicine, 3 (3), $781-786,2003$.

Dordetto, P. R., Pinto, G. C. \& Rosa , T. C. S. C. (2016). Patients undergoing cardiac surgery: sociodemographic characterization, clinical-epidemiological profile and complications. Magazine of the Faculty of Medical Sciences of Sorocaba, 18 (3), 144 - 9.

Gelijns, A. C. , Moslowitz, A. J., Acker, M. A., Argenziano, M., Geller, N. L., Puskas, J. D., Perrault, L. P., Smith, P. K., Kron, I. L., Michler, R. E., Miller, M. A., Timothy, J. T.,Ascheim, D. D., Ailawadi, G., Lackner, P., Goldsmith, L. A., Robichaud, S., Miller, R. A., Rose, E. A., Ferguson, T. B., Horvath, K. A., Moquete, E. G., Parides, M. K., Bagiella, E., O'Gara, P. T. \& Blackstone, E. H. (2014). Management Practices and Major Infections after Cardiac Surgery. Journal of the American College of Cardiology, 64 (4), 372-381.

IBM SPSS Statistics for Windows. IBM Corp, 2012. Software. 
Research, Society and Development, v. 10, n. 5, e14910514658, 2021

(CC BY 4.0) | ISSN 2525-3409 | DOI: http://dx.doi.org/10.33448/rsd-v10i5.14658

Laizo, A., Delgado, F. E. F. \& Rocha, G. M. (2010). Complications that increase the length of stay in the intensive care unit in cardiac surgery. Brazilian journal of cardiovascular surgery, 25 (2), 166-171.

Page, C. R. \& Eke, P. I. (2007). Case definitions for use in population-based surveillance of periodontitis. Journal Periodontology, 78 (7), $1387-1399$.

Paula e Silva, F. W. G., Queiroz, A. M., Díaz-Serrano, K. V., Silva, L. A. B. \& Ito, I. Y. (2010). Periapical inflammatory reaction: systemic repercussions? Clinical-Scientific Dentistry, 9 (4), 299-302.

Pereira, A. S. et al. (2018). Metodologia da pesquisa científica. UFSM. https://repositorio.ufsm.br/bitstream/handle/1/15824/Lic_Computacao_Metodologia Pesquisa -Cientifica.pdf?sequence $=1$

Quemelo, P. R. V., Milani, D., Bento, V. F., Vieira, E. R. \& Zaia, J. E. (2017). Health literacy: translation and validation of an instrument for research in health promotion in Brazil. Public Health Notebooks, 32 (2), 1-15.

Rohde, L. E., Montera, M. W., Bocchi, E. A., Clause II, N., Albuquerque, C. D. \& Rassi, S. (2018). Brazilian Guideline for Chronic and Acute Heart Failure. Brazilian Archives of Cardiology, 111 (3), 436-539.

Sabatier, C., Peredo, R. \& Valles, J. (2009) . Bacterial bloodstream infections in critical patients. Intensive Care Medicine, 33 (7), $336-45$.

Slade, G. D. (1997). Derivation and validation of a short-form oral health impact profile. Community Dent Oral Epidemiol, 25 (4), $284-290$.

Vettore, M. V., Marques, R. A. A., \& Peres, M. A. (2013). Social inequalities and periodontal disease in the SBBrasil 2010 study: a multilevel approach. Public Health, 47 (3), 29-39.

Yasny, J. S. \& White, J. (2009). Dental Considerations for Cardiac Surgery. Journal of Cardiac Surgery, 24 (1), 64-68. 